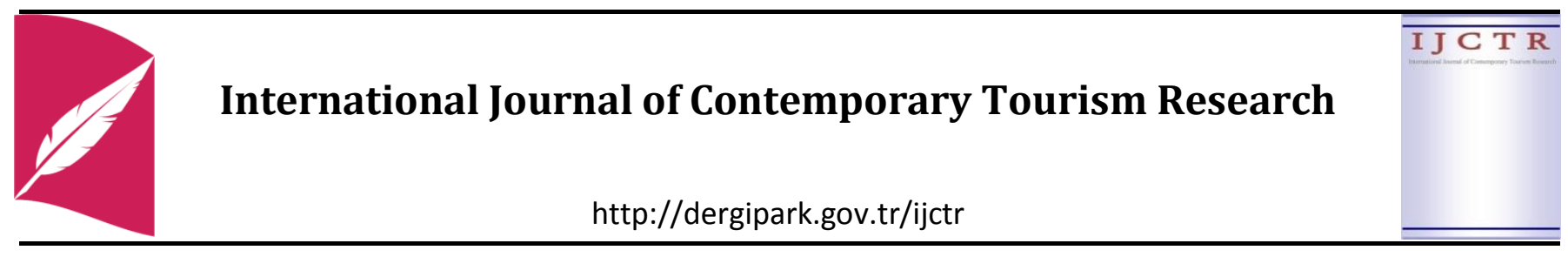

\title{
E-SPORT EVENTS WITHIN TOURISM PARADIGM: A CONCEPTUAL DISCUSSION Research Article
}

\author{
Sebahattin Emre DILEK*
}

\begin{abstract}
E-sports (electronic sports) refers to organized video gaming events or tournaments that culminate in championships at either the regional or international level. The e-sports market is experiencing rapid growth. By 2020, the market is expected to generate over US\$1.48 billion in revenue. The number of viewers who regularly follow the industry and tune in to watch international competitions is projected to reach 589 million by 2020 . There are many reasons why esports events are attractive and remarkable experiences: fans get the chance to (a) watch the best players in the world compete; (b) meet their favorite players; and (c) share their passion with hundreds of like-minded fans. This hip version of event tourism, e-sports tourism, has been flying under the radar for a long time but has finally, in recent years, entered the mainstream. This study discussed the relationship between e-sports and tourism by examining esports events within the tourism paradigm. Consequently, e-sports events, as a growing market, constitute an important attraction for the tourism sector.
\end{abstract}

Key Words: E-sports, events, e-sports event tourism, tourism paradigm

Jel Classification Codes: L83, G14

* Assistant Prof., School of Tourism and Hotel Management, Batman University, Batman, Turkey, s.emre.d@hotmail.com, orcid.org/ 0000-0001-7830-1928

"Dilek S. E. (2019). E-Sport Events Within Tourism Paradigm: A Conceptual Discussion, International Journal of Contemporary Tourism Research, Vol 3: No: 1, p12-22, doi: 10.30625/ijctr.525426" 


\section{INTRODUCTION}

Tourism has changed ontologically for decades. Demographic, socio-structural, socio-cultural, economic and technological developments have always driven changes in tourist demand and have forced suppliers in the industry to adjust substantially. With this in mind, various authors have pointed to people's desire for quality of life and escape from the "pluralisation of lifeworlds", and the "rationalization of contemporary urban life" as major motivators for travel (Rojek \& Urry, 1997; Giddens, 1999). Tourism suppliers to have focused on more homogeneous groups of tourists at the "hard or specialized" end of the market, described as "serious leisure participants", such as those seeking adventure tourism, event tourism, eco-tourism, sports tourism and cultural tourism (Trauer, 2006). Tourism consumption and production patterns, seen in the development of "special interest tourism", have come to reflect the increasing diversity of interests pursued in the latemodern leisure society. In other words, a bilateral exchange between tourism demand and supply has begun to influence the movement and growth of, and access to, new tourism experiences (Douglas, Douglas \& Derret, 2001).

Since the 2000s, internet-driven tourism has become increasingly important because of online communities centered around a specific or special interest, e.g., online gaming or 'modding', around the world (Cow \& Young, 2013). At the same time, the term 'event studies' was coined and used in passing in Getz's speech at the Events Beyond 2000 (Sydney) conference (Getz, 2008). As a consequence of these developments in tourism and technology, competitive computer gaming or "esport" emerged as a phenomenon, became a fundamental element in digital youth culture (Funk, Pizzo \& Baker, 2017), and has now started to impact the tourism industry as a new travelling motivation (Wagner, 2006; Yenişehirlioğlu, Erdoğan, Şahin \& Ulama, 2018).

E-sports, or 'electronic sports,' is the term used to refer to professional gaming. Young men and women from around the world make a living playing video games professionally, usually through prize pools in tournaments or from corporate sponsorships (McTee, 2014). The supply side of this phenomenon includes the business activities of content owners/providers (game developers, IP owners, game publishers, IP licensees), event organisers (leagues, tournaments, playoffs), media platforms (media companies, streaming technology companies), commercial brands (sponsors, advertisers), supporting services (training schools, coaches, commentators/casters), hardware/peripheral vendors and merchandisers (OGCIO, 2017). In summary, e-sports is a multidimensional term and a hallmark of the "experience economy" concept. Toffler noted that experiential products can be of two types. The first are "simulated environments" that are associated with computers, robotics, historical reenactments, museums, and so on. The second are "live environments" represented by experiential geographical hubs that, in many ways, are functionally like sports, travel/tourism, and gaming events (Toffler, 1970, p. 230). Thus, this study will discuss the relationship between e-sports and tourism by examining e-sports events within the tourism paradigm.

\section{DEFINING E-SPORTS AND E-SPORT EVENTS}

E-sport, in the form of organized video game competitions, is also known as cybersport, virtual sport, and competitive gaming (Jenny, Manning, Keiper \& Olrich, 2017). Popular genres of e-sport include fighting games (e.g. Street Fighter IV), first-person shooters (FPS) (e.g., Counter-Strike: Global Offensive or CS:GO), real-time strategy games (RTS) (e.g., StarCraft II), multiplayer online battle arenas (MOBAs) (e.g., League of Legends or LoL), and sport-based video games (SBVGs) (e.g., FIFA 17) (Funk et al., 2018). Organized e-sport events began in 1980, with Atari's Space Invaders Championship, the first major video game competition, drawing over 10,000 competitors ( $\mathrm{Li}$, 2016; Funk et al., 2018).

Wagner (2006, p. 438) defines e-sports as "an area of sport activities in which people develop and train mental or physical abilities in the use of information and communication technologies". Hamari and Sjöblom (2017, p. 5) define e-sports as "a form of sports where the primary aspects of the sport are facilitated by electronic systems; the input of players and teams as well as the output of the e-sports system are mediated by humancomputer interfaces". For Parshakov and Oskolkova (2016), e-sports have four characteristics. The first (1) is that the investment 
costs of e-sports are lower than for traditional team sports as sports facilities for spectator gaming are much cheaper, the investment required in e-sport players is less, and players can participate in multiple games on a professional level. The second (2) characteristic is, because e-sports is relatively new, no professional schools have been established to train players. The third (3) refers to the two types of tournaments that are held for most games offline (LAN) and online - with top tournaments and events held offline. Finally (4), the rewards and money won is mostly performance-based.

\section{RELATIONSHIP BETWEEN SPORT, TOURISM AND E-SPORT}

Sport, in its different forms, has always and continues to play an important role in every culture (Guttmann, 2004). Sport is also an important activity within tourism and tourism is a fundamental characteristic of sport (Hinch \& Higham, 2001); the concepts of tourism and sport are clearly related and overlap. Sport-related tourism has become increasingly important in the last few years both as an academic field of study and an increasingly popular tourism product (Gibson, 1998). According to Delpy (1998), sports tourism refers to travelling away from home to play sport, watch sport, or visit a sports attraction, including both competitive and non-competitive activities. Delpy (1998) also states that sports tourism can be broken down into five main categories: attractions, resorts, cruises, tours and events. Each of these categories is also related to other tourism sectors, such as adventure tourism, health tourism, nature tourism, educational tourism, leisure tourism, and virtual tourism.

In recent years, a new sporting activity has emerged and gained popularity among young people: e-sports, which in some respects challenges traditional sports (Jonasson \& Thiborg, 2010). E-Sport organizations such as the World Cyber Games (WCG), Electronic Sports World Cup (ESWC) and Cyberathlete Professional League (CPL), in cooperation with corporations within the computer game industry, arrange Local Area Network (LAN) competitions at both national and international levels (Hutchins, 2008; Jonasson $\&$ Thiborg, 2010). There are many reasons why esports events are attractive. Fans get the chance the watch the best players in the world compete, meet their favorite players and share their passion with hundreds of like-minded fans. For these reasons and more, fans are willing to travel thousands of miles to attend major events. There is, therefore, the potential for a new type of tourism to grow: esports tourism. In fact, Agius (2015) emphasized that the concept of e-sports as a niche tourism attraction is indeed viable, and with the significant interest already shown in this sector, it has the potential to become very profitable. On the other hand, other authors have stated that e-sports is an aspect of the recreation field and that e-sports tourism has already developed in modern society (Seo, 2016; Lokhman, Karashchuk \& Kornilova, 2018). E-sports is formally defined as 'an area of sport activities in which people develop and train mental or physical abilities in the use of information and communication technologies' (Wagner, 2007; Seo, 2013).

In other words, e-sports involves the interconnection between multiple platforms, unlike traditional sports such as hockey, baseball, and soccer (Ayar, 2018). E-sports, or competitive gaming, describes organized multiplayer video game competitions (Heere, 2018) and has, as both a professional sport and a form of entertainment, been developing at a rapid pace. Wouter Sleijffers, CEO of Fnatic, comments (Esreality, 2016): “Esports remains an industry with great potential for the years to come. E-sports is a very diverse space, and for established and worldwide e-sports brands like Fnatic, it's vital to follow the developments using reliable and complete data". The first wellrounded report on the global e-sports market was published by the market research firm Newzoo ${ }^{1}$ in 2015 in which it was estimated that e-sports generates US\$612 million and has 134 million viewers around the world. Following an analysis of the most recent data from 2015, it is estimated that the revenue in 2017 was US\$325 million worldwide. The coming year (in 2019) will see the e-sports economy grow to US\$463 million, a yearon-year growth of $43 \%$, and will entertain an audience of 131 million e-sports enthusiasts and another 125 million occasional viewers who mainly tune in for big international events (Newzoo, 2017). Newzoo estimates that the

\footnotetext{
${ }^{1}$ Newzoo is a leading global market intelligence firm that specializes in games, e-sports, and mobiles with offices in Amsterdam, San Francisco and Shanghai, and partner offices in six other cities around the world.
} 
industry will be worth US $\$ 1.5$ billion by 2020 (Tan, 2018). In sum, e-sports and e-sports events have experienced phenomenal growth over recent years and continue to grow annually.

\section{E-SPORTS EVENTS ECOSYSTEM}

E-sports is evaluated under two categories in the Newzoo report; audience scope and revenue scope (Newzoo, 2018). Revenue scope consists of professional competitive gaming and channels (teams, publishers, events and leagues) while amateur competitive gaming and all other gaming are included under audience scope. In this study, events that are one of the five components (channels, publishers, leagues, events and teams) have been scrutinized as a leisure activity. The scopes are shown in Figure 1.

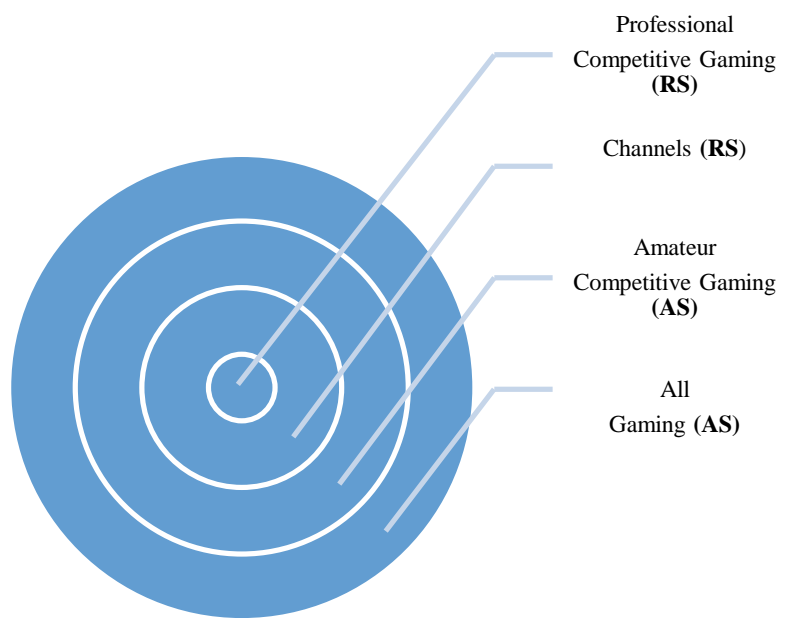

Figure 1. Audience Scope (AS) and Revenue Scope (RS) of E-Sports Ecosystem

Source:www.images.eurogamer.net/2014/dan.pearson/Newzo o_Preview_Images_Global_Growth_of_Esports_Report_V4.p df

As seen in Figure 1 above, e-sporting events are included in the second circle (channels) alongside teams, publishers and leagues. Participants attending e-sporting events are categorized under four different headings: (1) Regular Viewers (Participants): watch and regularly participate in (amateur) championships; (2) Occasional Viewers (Participants): watch and sometimes participate in (amateur) championships; (3) Regular Viewers: regularly watch professional and amateur competitive gaming; and (4) Occasional Viewers: occasionally watch professional and amateur competitive gaming.

As Internet-based gaming improved, so did the popularity of video games and the desire to spectate gaming online and in person. For example, the 2016 League of Legends (LoL) World Championship - the most popular e-sports tournament-attracted 21,000 live spectators, was broadcasted by over 23 entities in 18 languages, and garnered 47.7 million unique viewers with a peak concurrent viewership of 14.7 million people (Kresse, 2016). Moreover, e-sports attracts over \$500 million in sponsorships annually, including heavyweights Coca-Cola, Red Bull, Intel, and Nissan (Casselman, 2015). Moreover, e-sports attracts over $\$ 500$ million in sponsorships annually, including from heavyweights such as Coca-Cola, Red Bull, Intel, and Nissan (Casselman, 2015). As such, sponsors have taken notice and have begun to invest millions of dollars in sponsoring e-sports teams, events and tournaments. In 2016, 424 worldwide e-sporting events were held with prizes of more than $\$ 5,000$; in total, these prizes totaled $\$ 93.3$ million - over 50\% increase since 2015 (Newzoo, 2018). In short, e-sports revenue is fundamentally comprised of five components: (1) sponsorships; (2) advertising; (3) media rights; (4) game publisher fees; and (5) tickets and merchandise revenue. The revenue generated by e-sports is growing year-by-year, based on these components and the viewer numbers (see Table 1).

Table 1. E-Sport Revenue Growth

\begin{tabular}{|l|l|l|l|}
\hline Years & $\begin{array}{l}\text { Revenue } \\
\text { (Million \$) }\end{array}$ & $\begin{array}{l}\text { Change } \\
(\%)\end{array}$ & $\begin{array}{l}\text { Change } \\
\text { (Years) }\end{array}$ \\
\hline 2012 & 130 & - & - \\
\hline 2014 & 194 & $+49.2 \%$ & $(2012 / 14)$ \\
\hline 2015 & 325 & $+67.5 \%$ & $(2014 / 15)$ \\
\hline 2016 & 493 & $+51.6 \%$ & $(2015 / 16)$ \\
\hline 2017 & 655 & $+32.8 \%$ & $(2016 / 17)$ \\
\hline 2018 & 906 & $+38.3 \%$ & $(2017 / 18)$ \\
\hline $2019^{*}$ & 1187 & $+31 \%$ & $(2018 / 19)$ \\
\hline $2020^{*}$ & 1488 & $+25.3 \%$ & $(2019 / 20)$ \\
\hline $2021^{*}$ & 1650 & $+10.8 \%$ & $(2020 / 21)$ \\
\hline
\end{tabular}

Source: The data were taken from Statista (2018).

* estimated

Table 1 shows the global e-sports market revenue from 2012 to 2021. In 2012, the global e-sports market was valued at nearly US\$130 million. It is estimated that the global e-sports market revenue will reach US $\$ 1.65$ billion by 2020 . In terms of revenue, Asia was the biggest e-sports market overall, followed by North America and Europe (Jenny, Taylor, Keiper, Williams, Gawrysiak, 
Manning \& Tutka, 2018). The e-sports industry is expected to grow rapidly within the next years.

Sport, in its different forms, plays an important role in every culture, both in the past, and in the present (Guttman, 2004). The phenomenon of competitive computer gaming is, in some respects, challenging the hegemony of traditional sports. Unlike traditional organised sports, computer gaming is not a fully accepted leisure activity, and parents and adults do not encourage and support the activity in the same manner (Thiborg, 2009). However, e-sports are games, defined by Getz $(2005 ; 2008)$ as a recreational event in terms of the typology of planned events. In this regard, e-sports can be described as a leisure activity that is attracting increasing numbers of people around the world to participate (see Table 2).

Table 2. E-Sport Audience Growth

\begin{tabular}{|l|l|l|l|}
\hline Years & $\begin{array}{l}\text { Audience } \\
\text { (Million) } \\
\text { (Occasional } \\
\text { Viewers + } \\
\text { E-sport } \\
\text { Enthusiasts) }\end{array}$ & $\begin{array}{l}\text { Change } \\
(\%)\end{array}$ & $\begin{array}{l}\text { Change } \\
\text { (Years) }\end{array}$ \\
\hline $\mathbf{2 0 1 2}$ & $\mathbf{1 3 4}$ & - & - \\
\hline 2014 & 204 & $+52.2 \%$ & $2012 / 14$ \\
\hline 2015 & 235 & $+15.1 \%$ & $2014 / 15$ \\
\hline 2016 & 281 & $+19.5 \%$ & $2015 / 16$ \\
\hline 2017 & 335 & $+19.2 \%$ & $2016 / 17$ \\
\hline 2018 & 380 & $+13.4 \%$ & $2017 / 18$ \\
\hline $2019^{*}$ & 427 & $+12.3 \%$ & $2018 / 19$ \\
\hline $2020^{*}$ & 589 & $+37.9 \%$ & $2019 / 20$ \\
\hline $2021^{*}$ & 557 & $-5.4 \%$ & $2020 / 21$ \\
\hline
\end{tabular}

Source: The data were taken from Statista (2018). * estimated

Table 2 shows the global e-sports audience size from 2012 to 2021. In 2012, the number of frequent e-sports viewers and enthusiasts amounted to 134 million. This number is projected to reach 557 million in 2021. E-sports is profitable, not only for the industry as a whole, but also for individual players.

The statistics reveal the number of players participating in selected e-sports games worldwide as of August 2017. According to the data, League of Legends was the most popular e-sport based on the number of players.
Table 3. Number of players of selected e-sports games worldwide as of August 2017 (in million)

\begin{tabular}{|l|c|}
\hline Games and Events & $\begin{array}{c}\text { Number of Players } \\
\text { (million) }\end{array}$ \\
\hline League of Legends & 100.0 \\
\hline Call of Duty & 28.1 \\
\hline Hearthstone & 23.9 \\
\hline DOTA 2 & 12.6 \\
\hline World of Tanks & 12.3 \\
\hline FIFA 17 & 12.3 \\
\hline $\begin{array}{l}\text { Counter-Strike: } \\
\text { Global Offensive }\end{array}$ & 11.9 \\
\hline $\begin{array}{l}\text { PlayerUnknown's } \\
\text { Battlegrounds }\end{array}$ & 6.8 \\
\hline StarCraft II & 2.4 \\
\hline
\end{tabular}

Source: The data were taken from Statista (2018)

During 2017, the game had a player base of 100 million, while World of Tanks ranked fifth with 12.3 million players.

\section{E-SPORTING EVENTS TOURISM}

Consumer demand for e-sports and the growth of organized video game competitions has generated considerable attention from the sporting, event, tourism and entertainment industries (Funk et al., 2018). The relationship between sport and tourism has become increasingly important in the past few years. Gibson (2003) defines sports tourism as leisure-based travel that takes individuals temporarily out of their home communities to participate in physical activities, to watch physical activities, or to venerate attractions associated with physical activities. She suggests there are three types of sports tourism: active sports tourism (tennis, golf etc.), event sports tourism (the Olympic Games, world soccer championships etc.) and nostalgia sports tourism (stadiums, museums etc). Although e-sports does not depend on the physical abilities of participants in the way that traditional sports do (e.g. basketball, football or hockey), e-sports tourism can still be evaluated as a type of sports tourism, according to Gibson (2003), because e-sporting events attract the biggest audiences in the world (Peša, Čičin-Šain \& Blažević, 2017; Yu, 2018). According to the Statista report on the number of unique viewers of selected e-sporting events worldwide from 2012 to 2017, the Intel Extreme Masters Katowice that was held in Poland in 2017 was the most watched esports event, with a recorded 46 million unique viewers (Statista, 2018). The event included competitions in Counter Strike, League of Legends 
and Starcraft. The second most viewed tournament was the League of Legends World Championship held in the USA in October 2016, with 43 million unique viewers (Statista, 2018).

While the increase in the number of e-sports viewers is certainly an interesting trend from the perspective of the entertainment and tourism industries, it has become an even bigger factor for video game creators, distributors and travel agencies in recent times (Newzoo, 2016; Linscott, 2017; Peša et al., 2017). A positive correlation has been observed between the increase in the number of viewers, the sale of video games and the numbers travelling to attend e-sports events, which has recently attracted the attention of federal regulatory agencies and travel agencies (Eslgaming, 2014; Quinn, 2017). Furthermore, esports events offer consumer-perceived experiences in the context of special interest tourism. Pine and Gilmore (1998) identified four forms of consumer-perceived experience, known as the '4Es': educational, escapist, aesthetic, and entertainment experiences. Several studies have examined the role of the '4Es' in staging tourism experiences (Hosany \& Witham, 2010), such as heritage trails (Hayes \& McLeod, 2007) special events and wine tourism (Quadri-Felitti \& Fiore, 2012). Thus, e-sports events can be evaluated as special events tourism that offer a unique form of tourism product (Getz, 1989), and can be a primary source of motivation for thousands of people to travel (Yenişehirlioğlu et al., 2018) within the context of the '4Es' (see Figure 2).

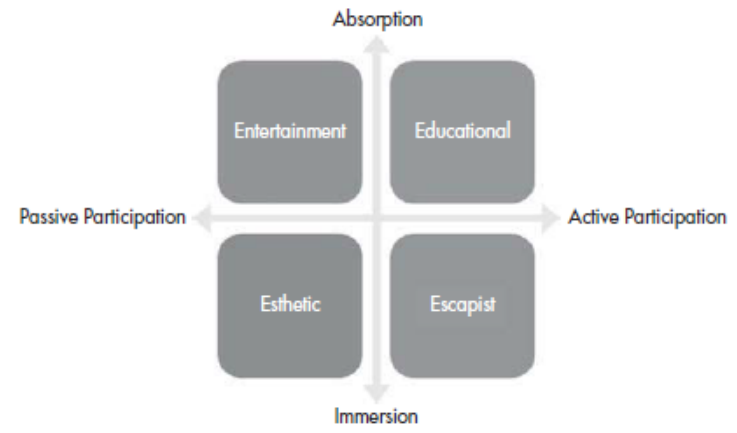

Figure 2. The '4Es' of e-sports events tourism

Source: Pine and Gilmore (1998)

As shown in Figure 2 above, experiences can be described based on their position on a horizontal axis with active participation at one end and passive participation at the other, and on a vertical axis with absorption at one end and immersion at the other (Pine \& Gilmore, 1998; 1999; 2011). The idea of the '4Es' is useful for understanding the experiential value of e-sports events tourism. First, escapist experiences involve active participation and immersion to the point where tourists actually have an effect on the performance or phenomenon, such as in e-sport events (Jurowski, 2009). Escapism represents the central feature of e-sports and of computer games consumption in general (Seo, 2016). It is embedded within performances that are fundamental to competitive computer gaming, i.e. the consumer's immersion into the playing of computer games as a form of sports (Wagner, 2007). On the other hand, aesthetic experiences, unlike escapist experiences, can be described as invoking a special state of mind that is qualitatively different from everyday experiences (Marković, 2012). According to Cupchik and Winston (1996), aesthetic experiences involve a psychological process in which attention is focused on an object while all other objects, events, and everyday concerns are suppressed. From this point of view, e-sports events tourism embody the aesthetic experience within spectacular environments including gaming companies, players, communities, broadcasting stations, sponsors, tour operators/travel agencies, and other tourism businesses (Kozinets et al.,, 2004; Seo, 2016).

Educational experiences are those that fall into the active absorption quadrant (see Figure 2). In this type of experience, participants actively absorb experiences into their mental state (Jurowski, 2009). This means that the consumer needs to be actively involved in the educational experience. Although the educational experience involves active engagement from participants, they are outside the event rather than immersed in the action (Pine \& Gilmore, 1998). E-sports events tourism facilitates educational experiences by providing opportunities for players to exchange various gameplay strategies and tactics, as well as their views on particular computer games and their personal experiences related to e-sports (Seo, 2016). Finally, another aspect of e-sports event tourism is entertainment. Entertainment refers to passive absorption such as reading a book, listening to music or watching an e-sports events. With the growing popularity of e-sports culture, consumers find pleasure not only in playing 
computer games as a form of sports, but also in watching others play computer games live, particularly if those others are exceptionally skilled players (Christophers \& Scholz, 2010, 2011; Seo, 2016).

This theoretical formulation - the '4Es' - offers a critical lens through which to explore e-sports events-related tourism. In other words, playing computer games competitively (escapism), attending e-sports events (aesthetic), learning about e-sports practices (educational), and watching esports (entertainment) are closely associated with the motivations of tourism participants. This is because the drivers for travel are the need to escape daily routines and the workplace, as well as social needs such as meeting other people, and experiencing something unique or unusual (Šimková \& Holzner, 2014). The motivational factors that drive people to become involved in the tourism industry as tourists/visitors differ greatly from person to person. In this regard, e-sports is one of the motivational factors that drives the attendance of tourism activities that are based on experience-based events, such as game playing or watching. Just as with traditional sports organizations, e-sports organizations can also be a primary source of motivation for thousands of people to travel.

\section{CONCLUSION AND DISCUSSION}

Observing in the way of tourism relevant aspects of sports events so far has shown that such events have a significant touristic potential. For centuries, people have gathered to watch sporting events. With the rise of e-sports, traditional sports are faced with a new rival. The rise of e-sports has already captured the interest of many sporting organisations, such as the football clubs Manchester City, West Ham, Paris Saint-Germain, Wolfsburg and Valencia, who have signed e-sports stars to represent them in tournaments of the popular football game, FIFA. The NBA teams Sacramento Kings, Golden State Warriors, Philadelphia 76ers and Milwaukee Bucks have also invested in League of Legends teams (Stewart, 2017). In addition, the Olympic Council of Asia (OCA) has announced that e-sports will be a medal sport at the 2022 Asian Games in China (Graham, 2017). Therefore, are e-sports real or traditional sports? E-sports are increasingly being accepted as sports, gamers are being seen as athletes by wider society, and parallels are being drawn between traditional sports and e-sports (Jenny, Manning, Keiper and Olrich, 2016). However, the virtual environment and the lack of physical activity in esports call into question whether we can truly define e-sports as "real sports" without any qualifiers (Parry, 2018). Prior research has examined e-sports in isolation from traditional sports, overlooking direct comparisons to understand the degree to which e-sport spectators are motivated in a similar way to traditional or real sport spectators (Pizzo, Baker, Na, Lee, Kim \& Funk, 2017). Many popular e-sports events/tournaments have drawn hundreds of participants from various continents, and this emerging sports genre is increasingly being recognized as a good spectator sport (Lee \& Schoenstedt, 2011).

When speaking about sports tourism events, several classification systems have been devised over the years. Weed and Bull (2004) classified sports tourism according to five different categories: (1) sports with tourism content (where sport is an incidental activity); (2) sportsparticipating tourism (where sport is the primary purpose of the trip); (3) sports training (the motivation for travel is sports training, ranging from beginner to advanced level); (4) sports events (the event is the primary motivation for the trip, either as a spectator or participant); (5) luxury sports tourism (concerning facilities, accommodation, and services). In this regard, observing in the way of tourism relevant aspects of e-sports events so far has shown that such events have a significant touristic potential. In addition, esports event tourism offer the concept of "edutainment", where education and entertainment meet (Creigthon, 1994), because this concept brings together education experience and entertainment experience of e-sport event tourism. Given that tourism is characterized by a heterogeneity of new and innovative venues marketed on the basis of their uniqueness, individuality or novelty (Dicks, 2003), 'edutainment' e-sports events/attractions can be defined as institutions that intentionally combine entertainment technologies and game content in formats that are characterized as maximizing, simultaneously, the educational and entertainment values of those contents. Hence, e-sports event tourism offers remarkable experiences: fans (a) get 
the chance to watch the best players in the world compete; (b) meet their favorite players; (c) share their passion with hundreds of like-minded fans; and (d) learn more about the games and events.

E-sports events have become popular because they provide visitors with two things that they seek simultaneously: (1) 'structured experiences that are high in entertainment value'; and (2) experiences which involve virtual-place attachment (events) that are culturally significant, meaningful and informative (Janiskee, 1996; Palmer, 2005; Hertzman, Anderson and Rowley, 2008). E-sports events are the 21 st century version of social activities. Instead of going to the football stadium to watch Arsenal vs. Liverpool, fans fill an arena as big as Anfield to follow a battle between the popular e-sports teams Fnatic and DC Dota2 (Schubert, Drachen and Mahlmann, 2016). For example, ESL One in Frankfurt (Germany) had an attendance of 52,000 people while the League of Legends World Final in Seoul (South Korea) saw 45,000 fans filling the Sangam Stadium (Traveling Churp, 2018). These events are therefore tourist attractions and are a new marketing landscape within the tourism paradigm (Seo, 2013; Borowy \& Jin, 2013; Ayar, 2018).

\section{References}

Agius, M. (2015). E-sports as a niche tourist attraction: an international exploratory study (B.A. Thesis), Institute for Tourism, Travel \& Culture, University of Malta.

Ayar, H. (2018). Development of e-sport in Turkey and in the world. International Journal of Science Culture and Sport, 6(1), 95-102.

Borowy, M. \& Jin, D. (2013). Pioneering eSport: The experience economy and the marketing of early 1980 s arcade gaming contests. International Journal of Communication, 7, 2254-2274.

Bull, C., \& Weed, M. (2012). Sports tourism: Participants, policy and providers. London: Routledge.

Casselman, B. (2015). Resistance is futile: eSports is massive and growing. [Online] Available: http://espn.go.com/espn/story/_/id/13059210/espor tsmassive-industry-growing

Christophers, J., \& Scholz, T. (Eds.) (2010). eSports Yearbook 2009. Norderstedt: Books on Demand GmbH.
Christophers, J., \& Scholz, T. (Eds.) (2011). eSports Yearbook 2010. Norderstedt: Books on Demand GmbH.

Creighton, M. R. (1994). "Edutaining" children: consumer and gender socialization in Japanese marketing. Ethnology, 33(1), 35-52.

Cupchik, G. C., \& Winston, A. S. (1996). Confluence and divergence in empirical aesthetics, philosophy, and mainstream psychology. In M.P. Friedman \& E.C Carterette,. (Eds.), Handbook of perception and cognition: Cognitive ecology (pp. 61-85). San Diego, CA: Academic Press, Inc.

Delpy, L. (1998). An overview of sport tourism: Building towards a dimensional framework. Journal of Vacation Marketing, 4(1), 23-38.

Dicks, B. (2003) Heritage, governance and marketization: A case-study from Wales. Museum and Society, 1(1), 30-44.

Douglas, N., Douglas, N. \& Derrett, R. (2001). Special interest tourism. Brisbane, AU: John Wiley and Sons Australia.

Eslgaming (2014). The growth and future of eSports tourism. [Online] Available: https://www.eslgaming.com/article/growth-andfuture-esports-tourism-1565

Esreality (2016). Global esports market report 2016. [Online] Available: http://www.esreality.com/?a=post\&id=2803572

Funk, D. C., Pizzo, A. D., \& Baker, B. J. (2018). eSport management: Embracing eSport education and research opportunities. Sport Management Review, 21(1), 7-13.

Getz, D. (1989). Special events: Defining the product. Tourism Management, 10(2), 125-137.

Getz, D. (2005). Event management and event tourism (2nd edition). New York, NY: Cognizant.

Getz, D. (2008). Event tourism: Definition, evolution, and research. Tourism Management, 29, 403-428.

Gibson, H. J. (1998). Sport tourism: a critical analysis of research. Sport Management Review, 1(1), 45-76.

Gibson, H. J. (2003). Sport tourism: An introduction to the special issue. Journal of Sport Management, 17(3), 205-213.

Giddens, A. (1999). Risk and responsibility. The Modern Law Review, 62(1), 1-10. 
Graham, B. A. (2017). eSports to be a medal event at 2022 Asian Games. [Online] Available: https://www.theguardian.com/sport/2017/apr/18/es ports-to-be-medal-sport-at-2022-asian-games

Guttmann, A. (2004). Sports: The first five millennia. Amherst and Boston, MA: University of Massachusetts Press.

Hamari, J., \& Sjöblom, M. (2017). What is eSports and why do people watch it?. Internet Research, 27(2), 211-232.

Hayes, D., \& MacLeod, N. (2007). Packaging places: Designing heritage trails using an experience economy perspective to maximize visitor engagement. Journal of Vacation Marketing, 13(1), 45-58.

Heere, B. (2018). Embracing the sportification of society: defining e-sports through a polymorphic view on sport. Sport Management Review, 21(1), 21-24.

Hertzman, E., Anderson, D., \& Rowley, S. (2008). Edutainment heritage tourist attractions: A portrait of visitors' experiences at Storyeum. Museum Management and Curatorship, 23(2), 155-175.

Hinch, T. D., \& Higham, J. E. (2001). Sport tourism: A framework for research. International Journal of Tourism Research, 3(1), 45-58.

Hosany, S., \& Witham, M. (2010). Dimensions of cruisers' experiences, satisfaction, and intention to recommend. Journal of Travel Research, 49(3), 351-364.

Hutchins, B. (2008). Signs of meta-change in second modernity: the growth of e-sport and the World Cyber Games. New Media \& Society, 10(6), 851-869.

Janiskee, R. L. (1996). Historic houses and special events. Annals of Tourism Research, 23(2), 398414.

Jenny, S. E., Keiper, M. C., Taylor, B. J., Williams, D. P., Gawrysiak, J., Manning, R. D., \& Tutka, P. M. (2018). eSports Venues: A new sport business opportunity. Journal of Applied Sport Management, 10(1), 34-49.

Jenny, S. E., Manning, R. D., Keiper, M. C., \& Olrich, T. W. (2017). Virtual (ly) athletes: Where eSports fit within the definition of "sport". Quest, 69(1), 1-18.
Jonasson, K., \& Thiborg, J. (2010). Electronic sport and its impact on future sport. Sport in Society, 13(2), 287-299.

Jurowski, C. (2009). An examination of the four realms of tourism experience theory. In Paper presented at the International CHRIE Conference Refereed Track, July 29, San Francisco.[Online]Available:http://scholarworks.u mass.edu/refereed/Sessions/Wednesday/23

Kozinets, R. V., Sherry Jr, J. F., Storm, D., Duhachek, A., Nuttavuthisit, K., \& DeBerrySpence, B. (2004). Ludic agency and retail spectacle. Journal of Consumer Research, 31(3), 658-672.

Kresse, C. (2016). eSports in 2015 by the numbers: Attendance figures, investments and prize money, Esports Marketing Blog. [Online] Available:http://esports-marketing-

blog.com/esports-in-2015-attendance-figuresinvestments-prize-money/

Lee, D., \& Schoenstedt, L. J. (2011). Comparison of eSports and traditional sports consumption motives. ICHPER-SD Journal Of Research, 6(2), 39-44.

Li, R. (2016). Good luck have fun: The rise of esports. New York, NY: Skyhorse Publishing, Inc.

Linscott, G. (2017). The first esports travel agency: Another milestone, [Online] Available: https://esportsedition.com/general/esports-travelgrowth/

Lokhman, N., Karashchuk, O., \& Kornilova, O. (2018). Analysis of esports as a commercial activity. Journal: Problems and Perspectives in Management, 16(1), 207-213.

Marković, S. (2012). Components of aesthetic experience: aesthetic fascination, aesthetic appraisal, and aesthetic emotion. $i$ Perception, 3(1), 1-17.

McTee, M. (2014). E-sports: More than just a fad. Oklahoma Journal of Law and Technology, 10(1), 1-27.

Newzoo (2016). Global e-sport market report. [Online] Available:

https://newzoo.com/insights/articles/globalesports-market-report-revenues-to-jump-to-463million-in-2016-as-us-leads-the-way/

Newzoo (2018). Global games market report 2018. [Online] 
Available:https://newzoo.com/insights/trendreports/newzoo-global-games-market-report-2018light-version/

Oakley, J. (2018). Why a travel and hospitality team is crucial for esports. [Online] Available:http://sportstravelmagazine.com/why-atravel-and-hospitality-team-is-crucial-for-esports/

OGCIO (2017). The Office of the Government Chief Information Officer (OGCIO) Report on Promotion of E-sports Development in Hong Kong. [Online] Available: https://www.ogcio.gov.hk/en/news/publications/do c/EN_e-sports_report.pdf

Palmer, C. (2005). An ethnography of Englishness: Experiencing identity through tourism. Annals of Tourism Research, 32(1), 7-27.

Parry, J. (2018). E-sports are Not Sports. Sport, Ethics and Philosophy, 1-16. https://doi.org/10.1080/17511321.2018.1489419

Parshakov, P., \& Oskolkova M. (2016). Success in eSports: Does Country Matter?. SSRN Scholarly Paper 2662343. [Online] Available: http://papers.ssrn.com/abstract=2662343

Peša, A. R., Čičin-Šain, D., \& Blažević, T. (2017). New business model in the growing e-sports industry. Business Excellence, 11(2), 121-132.

Pine, B. J., \& Gilmore, J. H. (1998). Welcome to the experience economy. Harvard Business Review, 76(4), 97-105.

Pine, B. J., \& Gilmore, J. H. (1999). The experience economy: Work is theatre and every business a stage. Boston, MA: Harvard Business Press.

Pine, B. J., \& Gilmore, J. H. (2011). The experience economy (Update edition). Boston, MA: Harvard Business Press.

Pizzo, A. D., Baker, B. J., Na, S., Lee, M. A., Kim, D., \& Funk, D. C. (2018). eSport vs. sport: A comparison of spectator motives. Sport Marketing Quarterly, 27(2), 108-123.

Quadri-Felitti, D., \& Fiore, A. M. (2012). Experience economy constructs as a framework for understanding wine tourism. Journal of Vacation Marketing, 18(1), 3-15.

Quinn, S. (2017). What are they thinking? Esports is not a game for the Hong Kong Tourism Board to play. [Online] Available: https://www.scmp.com/sport/hong- kong/article/2100854/what-are-they-thinkingesports-not-game-hong-kong-tourism-board-play Schubert, M., Drachen, A. \& Mahlmann, T. (2016). Esports analytics through encounter detection. In Sloan, M. I. T (Ed.), Proceedings of the MIT Sloan Sports Analytics Conference, 2016, Boston, USA.

Seo, Y. (2013). Electronic sports: A new marketing landscape of the experience economy. Journal of Marketing Management, 29(13-14), 1542-1560.

Seo, Y. (2016). Professionalized consumption and identity transformations in the field of eSports. Journal of Business Research, 69(1), 264-272.

Šimková, E., \& Holzner, J. (2014). Motivation of tourism participants. Procedia-Social and Behavioral Sciences, 159, 660-664.

Statista (2018). eSports market - Statistics \& Facts. [Online] Available: https://www.statista.com/topics/3121/esportsmarket/

Stewart, J. (2017). Why esports are real sports: Video gamers' talents compare with those of athletes and their tournaments rival viewing figures of sport events. [Online] Available:https://www.dailymail.co.uk/sport/esport s/article-4812762/Why-esports-real-sports.html

Tan, D. N. (2018). Owning the world's biggest esport: Intellectual property and Dota. Harvard Journal of Law \& Technology, 31(2), 965-989.

Thiborg, J. (2009). ESport and governering bodies - An outline for a research project and preliminary results. In: Kultur-Natur conference, Norrköping. Available: http://muep.mau.se/handle/2043/10746

Toffler, Al. (1970) Future shock. New York, NY: Random House.

Trauer, B. (2006). Conceptualizing special interest tourism-frameworks for analysis. Tourism Management, 27(2), 183-200.

Urry, J., \& Rojek, C. (Eds.). (1997). Touring cultures: transformations of travel and theory. London: Routledge.

Wagner, M. (2006). On the scientific relevance of eSport. In J. Arreymbi, V.A. Clincy, O.L. Droegehorn, S. Joan, M.G. Ashu, J.A. Ware, S. Zabir \& H.R. Arabnia (Eds.), Proceedings of the 2006 International Conference on Internet Computing and Conference on Computer Game 
Development (pp. 437-440), CSREA Press, Las Vegas, NV.

Wagner, M. (2007). Competing in metagame space - eSports as the first professionalized computer metagame. In F. von Borries, S. Walz, U. Brinkmann, \& M. Böttger (Eds.), Space time play - Games, architecture, and urbanism (pp. 182185). Basel, CHE: Birkhäuser.
Yenişehirlioğlu, E., Erdoğan, Ç. Şahin, S. \& Ulama, Ş. (2018). A conceptional research on determining the tourism potential of electronic sports events: E-sports tourism. The Journal of Kesit Academy, 4(16), 341-353.

$\mathrm{Yu}, \mathrm{H}$. (2018). Game On: The Rise of the eSports Middle Kingdom. Media Industries Journal, 5(1), 88-105. 